\title{
A BANALIZAÇÃO DO INSÓLITO NA MODERNIDADE LÍQUIDA: UMA LEITURA D'O EX-MÁGICO DA TABERNA MINHOTA, DE MURILO RUBIÃO
}

\author{
THE TRIVIALIZATION OF THE UNCOMMON IN TE LIQUID \\ MODERNITY: A READING OF THE EX-MAGICIAN OF THE \\ MINHOTA TAVERN, BY MURILO RUBIÃO
}

Marcela de Castro Ávila Aguiar ${ }^{1}$

Resumo: Este artigo propōe a investigaçăo do fantástico na obra do contista Murilo Rubiấo. Constitui-se da análise do conto "O ex-mágico da Taberna Minhota" publicado no primeiro livro do autor, O ex-mágico (1947), ancorada na teoria da modernidade líquida de Zygmunt Bauman (2001). O estudo tem como perspectiva a construçâo da identidade na literatura à época em que o autor produziu e publicou suas narrativas ficcionais e, para tanto, busca a conexăo entre essa produçâo literária e o contexto sócio-político brasileiro. Essa análise pretende demonstrar que a estética muriliana, mais que representar um novo modo discursivo na literatura brasileira, ilustrou aspectos da sociedade líquidomoderna, como a fluidez identitária, uma vez que esses contos retratam uma sociedade desordenada, cujas estruturas sociais sâo alteradas frequentemente, fazendo escapar ao sujeito um modo de se firmar como indivíduo e agente social.

Palavras-chave: Conto fantástico brasileiro. Insólito banalizado. Murilo Rubiāo.

Abstract: This paper proposes the investigation of the fantastic in the work of the short story writer Murilo Rubiano. It is an analysis of the short story "The ex-magician of the Minhota Tavern" published in the first book of the author, The ex-magician (1947), anchored in the theory of liquid modernity of Zygmunt Bauman (2001). The study has as perspective the construction of the identity in the literature of the time in which the author produced and published his fictional narratives and, therefore, searches the connexion between this literary production and the Brazilian social-political context. This analysis intends to demonstrate that the aesthetics muriliana, more than representing a new discursive way in the Brazilian literature, illustrated aspects of the liquid-modern society, such as the identity fluidity, since these short stories portray a disorderly society, which social structures are frequently altered, making escape to the subject a way of establishing himself as an individual and social agent.

Keywords: Brazilian fantastic short story. Trivialized uncommon. Murilo Rubiăo.

1 Doutoranda em Letras no Programa de Pós-Graduaçâo em Letras (PPGL) da Universidade Estadual Paulista "Júlio de Mesquita Filho" (UNESP), campus Săo José do Rio Preto, e-mail: marcela_mt@hotmail.com. 


\title{
O FANTÁSTICO: DA TRADIÇÃO AO MODO LITERÁRIO
}

A tarefa de pensar o insólito na ficçâo do escritor brasileiro Murilo Rubiâo compreende a revisâo teórica nâo apenas do Fantástico, como de seus vizinhos, o Estranho e o Realismo Maravilhoso, além do Sobrenatural e do Absurdo, que também apresentam longa tradiçâo literária. Os limites deste texto, no entanto, nos levam à mençâo de um e de outro com a finalidade única de delimitaçăo daquele que é o nosso objetivo maior a partir da escolha de analisar o estilo muriliano no contexto da produçâo literária brasileira em meados do século XX.

As raízes da literatura fantástica estăo nas lendas medievais e nas novelas góticas. O escritor e crítico H. P. Lovecraft (1890-1937), em O horror sobrenatural em literatura (1945), abordou a novela gótica tradicional até seus contemporâneos, mas nâo tratou da sua própria produçăo literária. A ele interessava caracterizar o gênero que tinha no horror o seu ponto fulcral:

\begin{abstract}
Os primeiros instintos e emoçóes do homem foram sua resposta ao ambiente em que se achava. Sensaçóes definidas baseadas no prazer e na dor se desenvolveram em torno dos fenômenos cujas causas e efeitos ele compreendia, enquanto em torno dos que năo compreendia - e eles fervilhavam no Universo nos tempos primitivos eram naturalmente elaborados como personificaçóes, interpretaçóes maravilhosas e as sensaçōes de medo e pavor que poderiam atingir uma raça com poucas e simples idéias, e limitada experiência. O desconhecido, sendo também o imprevisível, tornouse, para nossos ancestrais primitivos, uma fonte terrível e onipotente das benesses e calamidades concedidas à humanidade por razóes misteriosas e absolutamente extraterrestres, pertencendo, pois, nitidamente, a esferas de existência das quais nada sabemos e nas quais năo temos parte (LOVECRAFT, 2007, p. 14).
\end{abstract}

Ele sublinhou, ainda, que a emoçăo mais antiga experimentada pela humanidade é o medo, e o seu tipo mais instigante, o medo do desconhecido. Assim, a literatura que explorava o medo como sentimento estético só poderia ser compreendida e apreciada por um pequeno número de leitores sofisticados que se permitia, por meio de "um curioso rasgo de fantasia" (Ibid., p. 16), um distanciamento do cotidiano, do mundo que lhe era familiar. Além disso, o caráter de permanência da literatura do medo é ilustrado pelo fato de escritores com escolhas estéticas diferentes se aventurarem, vez ou outra, no terreno do sobrenatural.

O autor norte-americano também se preocupou em esclarecer que a literatura do "medo cósmico", diferentemente do medo físico e do horrível vulgar, caracterizava-se pela "atmosfera inexplicável e empolgante de pavor de forças externas desconhecidas" e pela "suspensão ou derrota maligna" das forças da Natureza que tudo explicam, livrando o sujeito "do caos e dos demônios dos espaços insondáveis" (Ibid., p. 17).

Sua análise dedicou-se, especialmente, à evoluçâo da representaçăo do medo na literatura desde o século XVII até os seus contemporâneos do início do século XX. Em sua análise, năo se preocupou tanto com a terminologia da literatura que buscava descrever, às vezes se referindo a ela como "de horror" ou "sobrenatural" e, em outras, optando por "literatura fantástica".

Essa questâo terminológica começou a ser mais bem trabalhada quando, em 1968, Tzvetan Todorov escreve Introduçâo à literatura fantástica, a fim de situar a produçâo 
literária de artistas do século XIX e início do século XX em cujas obras verificava-se a presença do elemento sobrenatural, mas que năo correspondiam às narrativas de horror descritas por Lovecraft (2007). O livro publicado por Todorov teve o mérito de organizar, reunir e discutir estudos anteriores, além de agrupar as produçôes literárias similares; daí a sua obra ter se tornado a principal fonte teórica para os pesquisadores do sobrenatural - como o insólito ficcional era chamado até entăo.

Na visăo todoroviana, a condiçâo essencial para que o Fantástico se constituísse seria a dúvida quanto à natureza de um acontecimento năo natural:

Num mundo que é exatamente o nosso, aquele que conhecemos (...), produz-se um acontecimento que năo pode ser explicado pelas leis deste mesmo mundo familiar. Aquele que o percebe deve optar por uma das duas soluçôes possíveis: ou se trata de uma ilusâo dos sentidos, de um produto da imaginaçấo e nesse caso as leis do mundo continuam a ser o que săo; ou entâo o acontecimento realmente ocorreu, é parte integrante da realidade, mas nesse caso a realidade é regida por leis desconhecidas para nós (TODOROV, 2007, p. 30).

Para esse crítico, "o âmago do fantástico" estaria na permanência da dúvida diante do acontecimento sobrenatural. Essa definiçấo originou-se, portanto, da oposiçăo entre o que é real e o que é tido como um elemento do imaginário (TODOROV, 2007, p. 48).

O Fantástico emergira no Iluminismo, quando do embate entre o natural e o năo natural, mas sem um vitorioso: a sua distinçáo era justamente a de que o năo natural năo era aceito ou refutado pelos personagens, uma vez que a estrutura narrativa nâo permitia que se explicasse aquele acontecimento que destoava do natural, ou seja, do que era tido como parte da realidade. $O$ desequilíbrio entre a presença do sobrenatural e a nâo soluçăo para ele instauravam a hesitaçăo. Esse traço diferencia o Fantástico do Realismo Maravilhoso que, ao năo questionar o elemento sobrenatural, cria uma realidade alucinada em que uma ordem deífica o explicaria; enquanto as narrativas do fantástico, ao năo conseguirem explicar o elemento sobrenatural racionalmente, terminam por assumir a falta de soluçăo.

Diante das narrativas do final do século XX, especialmente A metamorfose (1915), de Franz Kafka, Todorov (2007) se pergunta, no último capítulo de seu livro: “Em que se transformou a narrativa do sobrenatural do século XX?" (p. 177). Para ele, a Psicanálise havia substituído e inutilizado a literatura fantástica, uma vez que passou a tratar de tabus, loucuras e perversōes sem recorrer aos elementos do fantástico, mas considerando-os uma realidade específica dos pacientes que os manifestassem. Da mesma maneira, no século XX, năo se verificava mais o que Todorov (2007) chamara de "metafísica do real e do imaginário" e a crença em uma "realidade imutável" também perdera sustentaçáo (p. 176). Nesse sentido, realmente, a literatura fantástica descrita naquele seu modelo de análise desapareceu: "desta morte, deste suicídio nasceu uma nova literatura", concluiu o teórico. É nesta nova forma de narrativa que a obra de Franz Kafka estaria situada.

Hoje sabemos que Todorov formulou a definiçâo do fantástico tradicional e que a narrativa kafkiana e as que se seguiram apresentavam traços distintos e específicos que terminaram por afastar, em certa medida, os pesquisadores dos pressupostos todorovianos, mas que, ao mesmo tempo, promoveram uma atualizaçăo teórica. 
Um desses estudos que retomaram as principais ideias todorovianas e se dedicaram ao preenchimento das lacunas deixadas pelo teórico búlgaro foi o desenvolvido por Irène Bessière, em Le récit fantastique. La poétique de l'incertaine, publicado em Paris, no ano de 1974. No capítulo "O relato fantástico: forma mista do caso e da adivinha", a autora observou que grande parte da dificuldade expressa pela comunidade crítica em relaçăo ao estudo do fantástico à perspectiva teórico-metodológica adotada. Para ela, tratava-se de uma reduçăo atribuir a "organizaçăo do relato [fantástico] a um traço năo específico: a hesitaçâo" (BESSIÈRE, 2012, p. 305). Essa declaraçấo associava o universo fantástico a uma situaçăo inconsciente, excluindo todo o seu conteúdo semântico e, principalmente, as suas raízes na sociedade e na cultura.

Proceder à análise do fantástico daquela perspectiva năo levaria o estudioso a outro lugar senăo o das "enumeraçôes de imagens":

A síntese náo nasce aqui do inventário vasto e diverso dos textos, mas da organizaçáo, por contraste e por tensăo, dos elementos e das implicaçôes heterogêneas que fazem o atrativo do relato fantástico e sua unidade (BESSIĖRE, 2012, p. 305).

Bessière (2012) também ressaltou que a ênfase nas "referências teológicas, esotéricas, filosóficas ou psicopatológicas" nâo era recomendada, na medida em que esses elementos náo instauram o insólito na narrativa, nem mesmo garantem a sua permanência; săo, tăo somente, "artifícios narrativos destinados a encerrar o herói e o leitor em uma forma de paradoxo" (p. 306). Segundo a sua teria, o relato fantástico:

[...] utiliza marcos socioculturais e formas de compreensăo que definem os domínios do natural e do sobrenatural, do banal e do estranho, năo para concluir com alguma certeza metafísica, mas para organizar o confronto entre os elementos de uma civilizaçấo relativos aos fenômenos que escapam à economia do real e do surreal, cuja concepçăo varia conforme a época (BESSIĖRE, 2012, p. 306).

Percebemos que o que incomodou essa estudiosa foi o fato de se procurar o fantástico na reaçăo do leitor ou das personagens ao elemento insólito, quando o fantástico seria uma construçấo, um trabalho com a linguagem que "coloca em açăo dados contraditórios, reunidos segundo uma coerência e uma complementaridade próprias" a fim de incitar a incerteza (BESSIÈRE, 2012, p. 307). O Fantástico, para essa teórica, era entendido como um modo literário passível de assumir diversas formas - assim, seria possível ampliar as suas possibilidades de ocorrência na literatura universal, mesmo em obras posteriores às estudadas por Todorov, como as narrativas kafkianas.

O ponto comum nos estudos de Todorov e Bessière era o elemento insólito - que nos estudos de ambos era denominado "sobrenatural", no sentido de náo natural. A discordância entre suas teorias assenta-se na concepçăo genológica e modal. A esse respeito, Gama-Khalil (2013) observa que:

Alguns estudos tentam organizar as diversas formas da narrativa fantástica e agrupá-las em 'gêneros'. Nesse caso, dando ênfase às diferenças, demarcam territórios em que o fantástico ficará situado ao lado dos gêneros vizinhos. Em outra linha de entendimento, teóricos procuram compreender essa literatura por uma visăo que privilegia năo somente a diferença, mas as similitudes e, nesse sentido, adotam a perspectiva do 'modo' (GAMA-KHALIL, 2013, p. 19). 
A pesquisadora ressalta que, para Todorov (2007), a hesitaçăo caracteriza o gênero fantástico; já na concepçăo adotada por Bessière (2012), o que define o modo literário fantástico é a convivência harmônica entre o comum e o incomum.

Também outros críticos pensaram essa questăo, como Felipe Furtado. Apesar de sua obra principal ter sido escrita em 1980 - A construçâo do fantástico na narrativa - e se mostrar bastante alinhada à teoria todoroviana que entendia o fantástico como um gênero; citamos um texto mais atual, no qual o crítico português colabora com o Dicionário de Termos Literários de Carlos Ceia. No verbete "Fantástico: Modo", Furtado (2009) explica a coexistência do fantástico genológico, tradicional, cujas características haviam sido descritas por Todorov (2007); e o fantástico modal, que ora apresentava:

Perante o grande número e a heterogeneidade dos textos (e, mesmo, dos géneros) aqui envolvidos, convém examinar com alguma atençăo aquilo que invariavelmente surge em qualquer deles e justifica, portanto, a sua subsunçăo no modo fantástico. Trata-se, afinal, do único factor que, a despeito da sua índole extraliterária é comum a todos: o conceito geralmente designado por sobrenatural. (...) o vocábulo tem servido ao longo de eras para referir uma multidăo heterogénea de elementos, desde as fadas, os espectros ou as divindades das diversas religiôes aos casos de percepçáo extra-sensorial e às figuras monstruosas de lendas populares como o lobisomem ou o vampiro. Para além de muito diversificados, estes elementos variam com as épocas e as culturas em que surgem e vigoram. Portanto, modificam-se, desaparecem ou passam a sobreviver residualmente nas artes e na memória colectiva conforme o conhecimento invade o real, explorando as largas zonas de sombra que nele ainda subsistem (FURTADO, 2009, p. 1).

Para Furtado (2009), a literatura fantástica seria mais bem estudada e compreendida da perspectiva modal, por considerar o elemento sobrenatural um agregador de diferentes formas e até mesmo gêneros literários (p. 1).

Em estudo recente sobre os efeitos de se tomar o Fantástico como gênero ou modo, Flávio García sintetiza que:

Como gênero literário, o fantástico estaria restrito àquela ficçáo cuja explicaçăo buscada para o insólito fosse impossível, mantendo-se narrador, narratário, personagens e leitor real em dúvida permanente, hesitantes diante das opçóes que se lhe apresentam, sem o poder decidir até o final da narrativa. (...) Como modo discursivo [ou literário], bastaria ao fantástico a manifestaçāo do insólito, deixando narrador, narratário, personagens e leitor real na incerteza diante das explicaçóes que se lhes apareçam como possíveis, sem que uma delas anule as demais (GARCÍA, 2011, p. 3).

Na mesma linha de Bessière (2012), o crítico Prada Oropeza (2006), no artigo “El discurso fantástico contemporâneo: ténsion semântica y efecto estético", assim se referiu às narrativas fantásticas produzidas a partir da segunda década no século XX (em oposiçấo à narrativa realista):

[...] en la narración fantástica se hace evidente una 'ruptura' en la codificación realista que el mismo 'lo extraño', lo que no cuadra con la coherencia realista, y le confiere su valor propio, contrario a la lógica aristotélicaracionalista. De este modo, en el seno mismo del universo racional de las cosas surge lo 'incoherente' con ese reino, lo que llamamos insólito (PRADA OROPEZA, 2006, p. 58). 
Prada Oropeza (2006) percebe a existência de ao menos dois sistemas narrativo-literários: um realista, fiel à realidade extratextual; outro insólito que, ao romper com a representaçấo coerente, provoca uma ranhura no imaginário ficcional. Parece-nos, entấ, que existe uma tendência nos estudos críticos atuais de se pensar o Fantástico da perspectiva modal.

A partir de nosso entendimento desses pressupostos teóricos, ao lermos os contos do escritor brasileiro Murilo Rubiâo percebemos que de fato năo ocorre a elaboraçăo de outra realidade ou outro mundo, de onde ou para o qual personagens fossem deslocados, e sim a convivência de duas realidades ou, melhor dizendo, de um mundo com as características do mundo tal qual o conhecemos, aceitamos e vivenciamos, mas com a presença de elementos e/ou situaçóes incomuns.

Esse breve percurso acerca do Fantástico literário pode explicar o fato de a obra de Murilo Rubiâo ter destoado, pode-se assim dizer, das demais produçôes literárias de sua época. Esses estudos críticos foram produzidos a partir da década de 70, mas o autor mineiro já produzia desde a década de 30 , quando a cena literária brasileira estava representada, de um lado, pelo "romance [realista] regionalista" de Graciliano Ramos, Érico Veríssimo e José Lins do Rego, entre outros; enquanto, de outro, Joâo Guimarăes Rosa e Clarice Lispector começavam a se firmar como os nomes mais expressivos daquelas produçôes consideradas inovadoras tanto na forma, quanto na temática.

A produçáo de contos, portanto, ainda estava presa ao modelo formal realista, do qual Rubiâo procurou se desvencilhar - năo por se opor a esse modelo, mas como resposta a um questionamento interno que o artista se coloca e que o norteia em sua vida criativa. Podemos pensar a escolha pela narrativa insólita como uma alternativa ao que era conhecido e valorizado pela crítica especializada, uma vez que o insólito muriliano é bastante diferente do que a historiografia literária brasileira havia registrado até entáo, como em Noite na Taverna, de Aluísio Azevedo, e em alguns contos de Machado de Assis.

Murilo Rubiăo publicou o seu primeiro livro em 1947. Entretanto, só a partir de 1970 alcançou certo reconhecimento de público e crítica. 0 autor afirmava, em entrevistas, que nada havia de extraordinário em sua produçấo, afinal, o insólito e o absurdo estavam no mundo à sua volta (WERNECK, 2006, p. 8) e ele, como muitos autores, escrevia sobre o que via. Dentre as suas leituras inspiradoras estavam a Bíblia, Machado de Assis, as lendas germânicas e a mitologia grega. Se a partir dessas leituras fôssemos enumerar três aspectos de sua obra, diríamos: as epígrafes bíblicas em todos os contos, o cuidado com a forma e a presença do elemento insólito.

A respeito dos dois primeiros, Jorge Schwartz (1981) observou que a reescritura e as republicaçóes dos contos já săo um traço fantástico da produçăo literária do autor, uma vez que Murilo Rubiăo reescreveu muito mais que escreveu (p. 2). Além disso, a geraçăo de escritores modernistas demonstrava uma preocupaçăo com a linguagem no sentido de moldá-la aos novos tempos, de aproximar a literatura brasileira das novidades difundidas na Semana de 22. Schwartz (1981) também demonstrou que as epígrafes bíblicas conferem circularidade à obra muriliana, uma vez que esses excertos configuram-se como narrativas autônomas e, simultaneamente, complementares à temática dos contos (p. 3). Propomos, aqui, o exame do terceiro aspecto - o insólito -, a partir da leitura do emblemático "O ex-mágico da Taberna Minhota", conto publicado 
no livro de estreia; e, também, a aproximaçáo da contística muriliana da teoria da "modernidade líquida" proposta pelo sociólogo Zygmunt Bauman.

O nosso pressuposto é de que a angústia do protagonista de “O ex-mágico da Taberna Minhota" resulta da sua condiçăo de nâo ter um passado e as vivências que conferem a todos uma identidade. Esse personagem passa a sua curiosa existência sendo levado pelos acontecimentos e năo consegue entender o seu lugar nessa sociedade.

\title{
UM MÁGICO ANGUSTIADO NA SOCIEDADE LÍQUIDA
}

\begin{abstract}
Nâo se trata absolutamente de fuga para o sonho ou o irracional. Quero dizer que preciso mudar o ponto de observaçăo, que preciso considerar o mundo sob outra ótica, outra lógica, outros meios de conhecimento e controle.
\end{abstract}

(CALVINO, 1990, p. 18)

"Hoje sou funcionário público e este nâo é o meu desconsolo maior" (RUBIÂO, 1986, p. 53) - a primeira linha do conto "O ex-mágico da Taberna Minhota" (1947) apresenta-nos um narrador-protagonista que, no tempo presente da narrativa, mostra-se insatisfeito com a sua existência. Ainda no título, o prefixo "ex" sugere mudança de estado. Essa e outras transformaçóes serăo narradas em flashback.

Ao mergulhamos na história desse sujeito, o leitor poderia se perguntar: que angústias seriam essas? ou que experiências seriam responsáveis por esse sentimento desolador?. A primeira notaçăo curiosa é quando ele se descobre já adulto, olhando-se no espelho de um restaurante, refletindo sobre a falta de um passado:

Na verdade, eu năo estava preparado para o sofrimento. Todo homem, ao atingir certa idade, pode perfeitamente enfrentar a avalanche do tédio e da amargura, pois desde a meninice acostumou-se às vicissitudes, através de um processo lento e gradativo de dissabores. Tal năo aconteceu comigo. Fui atirado à vida sem pais, infância ou juventude (RUBIÂO, 1986, p. 53).

Vemos que o protagonista já constitui um elemento incomum na narrativa, no sentido de năo ser como "todo homem":

A descoberta năo me espantou e tampouco me surpreendi ao retirar do bolso o dono do restaurante. Ele sim, perplexo, me perguntou como podia ter feito aquilo. O que poderia responder, nessa situaçáo, uma pessoa que năo encontrava a menor explicaçăo para a sua presença no mundo? Disse-lhe que estava cansado. Nascera cansado e entediado. Sem meditar na resposta, ou fazer outras perguntas, ofereceume um emprego (...) (RUBIÂO, 1986, p. 53).

O mágico passa a entreter os clientes do restaurante com seus truques e, em seguida, é contratado pelo Circo-Parque Andaluz. Paralelamente ao percurso que chamaremos 'sucesso do mágico', constrói-se outro, o da 'indiferença do mágico'. Tais percursos, no plano da narrativa, săo representados pelas oposiçôes: "empolgavam multidôes" x "resmungava contra o mundo"; "deram fabulosos lucros" x "minha indiferença"; 
"os assistentes vibravam" x "meu olhar distante". Essas construçóes demostram que mesmo obtendo a graça do público, o mágico náo se conecta a ele. Na segunda parte do conto, separada da anterior por um espaço em branco, o narrador-protagonista começa a perder o controle sobre suas mágicas e isso se torna um incômodo:

Às vezes, sentado em algum café, a olhar cismativamente o povo desfilando na calçada, arrancava do bolso pombos, gaivotas, maritacas. As pessoas que se encontravam nas imediaçóes, julgando intencional o meu gesto, rompiam em estridentes gargalhadas. [...] Quase sempre, ao tirar o lenço para assoar o nariz, provocava o assombro dos que estavam próximos, sacando um lençol do bolso. Se mexia na gola do paletó, logo aparecia um urubu. Em outras ocasiôes, indo amarrar o cordăo do sapato, das minhas calças deslizavam cobras. Mulheres e crianças gritavam. Vinham guardas, ajuntavamse curiosos, um escândalo (RUBIÂO, 1986, p. 55).

Inicia-se um novo percurso: 'tentativa de pôr fim à própria vida'. Na terceira parte, o mágico tenta se matar inúmeras vezes, mas é sempre salvo por algum truque. Ouve, entấo, um "homem triste" dizer que "ser funcionário público era suicidar-se aos poucos" (Ibid., p. 56), e decide se empregar em uma repartiçấo pública. Interessante notar que uma expressăo do discurso figurado (a fala do homem) é empregada em seu sentido denotado (a reaçâo do ex-mágico), assim como Todorov (2007) apontou ao analisar os recursos responsáveis pelo efeito de sentido do fantástico.

A quarta divisáo interna do conto trata das primeiras impressōes do agora ex-mágico acerca da sua nova ocupaçâo:

Năo morri, conforme esperava. Maiores foram as minhas afliçóes, maior o meu desconsolo. Quando era mágico, pouco lidava com os homens - o palco me distanciava deles. Agora, obrigado a constante contato com meus semelhantes, necessitava compreendê-los, disfarçar a náusea que me causavam (Ibid., p. 56).

Também no novo emprego, o narrador-protagonista se vê apaixonado pela datilógrafa, mas năo consegue ser notado por ela. O desassossego volta a tomar conta. Na quinta parte da narrativa, mais um desafio: defender o emprego após "ameaças de demissóes coletivas" para năo se afastar da colega de trabalho por quem se apaixonara. A sua conversa com o "chefe da seçăo" năo é bem sucedida e o ex-mágico deseja ser salvo pelos antigos truques: "Revolvi, ansioso, todos os bolsos e nada encontrei. Tive que confessar minha derrota. Confiara demais na faculdade de fazer mágicas e ela fora anulada pela burocracia" (Ibid., p. 57).

Percebemos, nesse ponto, que o protagonista passa de um estado em que 'pode fazer mágicas, mas nâo quer' para o estado em que 'quer fazer mágicas, mas năo pode'. A parte final do conto retorna ao presente da narrativa: "Hoje, sem os antigos e miraculosos dons de mago, năo consigo abandonar a pior das ocupaçóes humanas" (p. 57). As últimas palavras sáo de desalento. 0 ex-mágico parece compreender, embora tarde, haver desperdiçado o dom de "mudar o mundo".

A hipérbole e a reiteraçăo sâo recursos estilísticos recorrentes nos contos de Murilo Rubiâo e trazem para o plano da narrativa as imagens da crise interna do sujeito da modernidade. Estăo presentes nas mágicas involuntárias e descontroladas do mágico, assim como na história da mulher que năo controla os seus desejos e, a cada pedido que faz ao marido, engorda exageradamente ("Bárbara"); do edifício sem funçâo alguma que năo pára de crescer ("O edifício”); do convidado que năo encontra a saída de 
uma festa cujo anfitriăo ninguém vê (“O convidado”); da fila infinita cuja existência e finalidade ninguém sabe explicar ("A fila") - algumas das muitas imagens criadas por Murilo Rubiâo que podem ser lidas como metáfora da crise interna pela qual passa o sujeito da modernidade.

Ao pensarmos na atualidade da narrativa de Murilo Rubiăo, identificamos uma correspondência com a metáfora da liquidez, em que o ex-mágico seria uma representaçâo do sujeito da "sociedade líquida" descrita por Zygmunt Bauman.

Este sociólogo humanista optou por chamar "modernidade líquida" ao que outros sociólogos e filósofos chamaram pós-modernidade. À modernidade líquida ele contrapōe a "modernidade sólida", que representa o início da era moderna, a que outros se referem apenas como "modernidade", a exemplo do filósofo francês Jean-François Lyotard (1924-1998), que adotou "pós-modernidade" para se referir à contemporaneidade.

Para Bauman, sua escolha terminológica se justifica, entre outros, pelo fato de a nossa sociedade ainda se manter "eminentemente moderna em suas ambiçóes e modus operandi (ou seja, no seu esforço de modernizaçâo compulsiva e obsessiva)" (PALLARES-BURKE, 2004, p. 320). O que ocorreu foi apenas a crise e o esvaziamento da estrutura que foi sustentaçăo da era moderna: a do Estado como protagonista dessa organizaçăo social. A transformaçăo dessa organizaçăo se deu com o aumento do poder do setor privado e a consequente retirada do Estado.

As ideologias "fortes", "pesadas", de caráter orientativo da modernidade sólida, esgotaram-se e, em consequência disso, temos o período de crise em que vivemos. A modernidade líquida é a "modernidade sem ilusōes", diz Bauman:

Diferentemente da sociedade modernaanterior, a que eu chamode modernidade sólida, que também estava sempre a desmontar a realidade herdada, a de agora năo o faz com uma perspectiva de longa duraçăo, com a intençăo de torná-la melhor e novamente sólida. Tudo está agora sempre a ser permanentemente desmontado, mas sem perspectiva de nenhuma permanência (PALLARESBURKE, 2004, p. 321).

Bauman (2001) observa que o aspecto principal da natureza dos fluidos é a possibilidade de assumirem diferentes formas, uma vez que "năo fixam espaços nem prendem o tempo" (p. 8), sâo por ele modificados; enquanto os sólidos "têm dimensôes espaciais mais claras (...), neutralizam o impacto" (p. 8) e resistem ao tempo.

Nesse sentido, a modernidade líquida está marcada pela fragmentaçăo e pela náo permanência de ideologias, posicionamentos, teorias etc., o que influencia o homem e seus relacionamentos consigo próprio e com a sociedade:

A desintegraçăo da rede social, a derrocada das agências efetivas de açấo coletiva, é recebida muitas vezes com grande ansiedade e lamentada como 'efeito colateral' năo previsto da nova leveza e fluidez do poder cada vez mais móvel, escorregadio, evasivo e fugitivo. Mas a desintegraçâo social é tanto uma condiçăo quanto um resultado da nova técnica do poder, que tem como ferramentas principais o desengajamento e a arte da fuga. Para que o poder tenha liberdade de fluir, o mundo deve estar livre de cercas, barreiras, fronteiras fortificadas e barricadas. Qualquer rede densa de laços sociais, e em particular uma que esteja territorialmente enraizada, é um obstáculo a ser eliminado (Ibid., p. 22). 
O pensamento de Bauman retoma os trabalhos de importantes sociólogos dos séculos XIX e XX, como Durkheim (1858-1917), Simmel (1858-1918) e Weber (1864-1920) e também dialoga com pensadores como Marx (1818-1883), Benjamin (1892-1940) e Derrida (1930-2004). A questăo do sujeito fragmentado, por exemplo, recupera a teoria de George Lukács que, em A teoria do romance (2007), constatou que o "colapso do mundo objetivo" resultou nessa fragmentaçâo: "(...) somente o eu permanece existente, embora também a sua existência dilua-se na insubstancialidade do mundo em ruínas criado por ele próprio" (LUCÁKS, 2007, p. 52).

As relaçōes humanas nesses tempos líquidos, consequentemente, săo marcadas pela superficialidade e volatilidade. Bauman (2001) retomou Jean Paul Sartre, em 0 existencialismo é um humanismo (1987) - que, na década de 40, escreveu que "o homem nada mais é do que o seu projeto; só existe na medida em que se realiza; năo é nada além de um conjunto de seus atos" (SARTRE, 1987, p. 13) - a fim de pensar o lugar do "projeto de vida" em um mundo caracterizado pela fluidez. Naquela época, era possível se pensar no sujeito que traçava um "plano", a ser perseguido com afinco, passo-a-passo, a fim de alcançar sucesso em sua existência:

Na época da modernidade sólida, quem entrasse como aprendiz nas fábricas da Renault ou da Ford iria com toda a probabilidade ter ali uma longa carreira e se aposentar após 40 ou 45 anos. Hoje em dia, quem trabalha para Bill Gates por um salário talvez cem vezes maior năo tem ideia do que poderá lhe acontecer dali a meio ano! $\mathrm{E}$ isso faz uma diferença incrível em todos os aspectos da vida humana (PALLARES-BURKE, 2004, p. 322).

O sujeito da modernidade líquida parece năo sustentar um mesmo projeto de vida devido à transitoriedade de seus desejos e objetivos, além, é claro, do fato de ser apenas mais um elemento flutuante desse ambiente sócio-político.

A sociedade líquido-moderna passou por mudanças que instauraram um novo clima cultural. A passagem da vida segura para a vida precária e incerta foi uma dessas mudanças. Em Vida líquida (2007), Bauman retoma a análise sobre a segurança que os fortes ideais que fundavam a modernidade sólida proporcionavam à sociedade para expor a crise de segurança que a sociedade líquida experimentou ao perder aquelas referências:

As preocupaçóes mais intensas e obstinadas que assombram este tipo de vida săo os temores de ser pego tirando uma soneca, năo conseguir acompanhar a rapidez dos eventos, ficar para trás, deixar passar as datas de vencimento, ficar sobrecarregado de bens agora indesejáveis, perder o momento que pede mudança e mudar de rumo antes de tomar o caminho de volta (BAUMAN, 2007, p. 8).

Além dessa precariedade e do caos existencial dela decorrente, a passagem da modernidade sólida para a líquida está marcada pelo confronto entre as ideias de eternidade e infinitude. Quando a sociedade estava segura quanto às bases ideológicas, podia-se pensar em eternidade no sentido metafísico. A modernidade em crise, no entanto, náo pode pensar em valores eternos, e sim na infinitude:

A eternidade é o óbvio rejeitado. Mas năo a infinitude. Enquanto esta durar o presente permanece, o dia de hoje pode-se esticar para além de qualquer limite e acomodar tudo aquilo que um dia se almejou vivenciar apenas na plenitude do tempo (Ibid., p. 14-5). 
Essa noçăo de infinitude é existencial e compreende o esticamento do tempo presente - o que, voltando ao projeto de vida sartreano, explica a impossibilidade de se hipotetizar uma vida futura.

"A vida passou a ser dividida em episódios" - podemos associar essa fala do Bauman (2011) ao texto do Ricardo Piglia (2004), sobre o conto moderno, para justificar o fato de o conto ser considerado a narrativa da modernidade.

Piglia (2004) elenca duas teses sobre o conto. A primeira, "um conto sempre conta duas histórias" (p. 89), é explicada a partir da estrutura do conto clássico, no qual a história 1 é aparente, e a história 2, a que é construída secretamente; o final surpreendente se dá quando a história 2 surge na superfície, e todos os conflitos instaurados sâo resolvidos. A segunda tese é a de que "a história secreta é a chave da forma do conto e de suas variantes" (p. 91), e ressalta a importância da técnica do contista, uma vez que o seu mérito está em cifrar a segunda narrativa que é, na verdade, o enredo principal.

O conto moderno, por sua vez, abandonou a divisăo clara entre realidades. Passase, entăo, a uma narrativa que "abandona o final surpreendente e a estrutura fechada; trabalha a tensăo entre as duas histórias sem nunca resolvê-las" (PIGLIA, 2004, p. 91). Nesse sentido, é possível pensar nessa tese como reveladora da forma de narrativa que representa a sociedade líquida baumaniana. Parece razoável, também, que a questâo da reescrita muriliana, além de ser uma representaçâo do artista sensível às transformaçôes de ordem estrutural e formal do conto, no contexto da literatura brasileira pós-Geraçăo de 1930, indica que o autor carregava as angústias existenciais, comuns a qualquer época, mas que se agravaria na modernidade líquida.

Ao retomarmos os primeiros parágrafos do conto analisado, onde o protagonista declara năo ter tido infância ou adolescência, o que o impossibilita de explicar a sua existência ao dono do restaurante (e a si próprio), fica evidente a ideia de "deslocamento do sujeito" - expressâo que Bauman procura desenvolver em Identidade (2005). Nessa obra, Bauman utiliza elementos de sua biografia ao falar do deslocamento.

De família judia polonesa, no início da Segunda Guerra Mundial, fugiu da ex-Uniăo Soviética e se alistou no Exército a fim de lutar contra o nazismo. Os estudos sociológicos vieram depois, quando estava na Varsóvia, onde se envolveu em movimentos intelectuais reformistas, que desafiavam o partido comunista polonês (BAUMAN, 2005, p. 16). O resultado foi uma nova fuga, desta vez para a Inglaterra, onde fixou residência e vive até hoje. Dessa sua condiçăo de refugiado, o autor percebeu que năo importava o lugar, ele estaria sempre "deslocado":

\begin{abstract}
Estar total ou parcialmente 'deslocado' em toda parte, năo estar totalmente em lugar algum (ou seja, sem restriçôes e embargos, sem que alguns aspectos da pessoa 'se sobressaiam' e sejam vistos por outras como estranhos), pode ser uma experiência desconfortável, por vezes perturbadora. Sempre há alguma coisa a explicar, desculpar, esconder ou, pelo contrário, corajosamente, ostentar, negociar, oferecer e barganhar. (...) As 'identidades' flutuam no ar, algumas de nossa própria escolha, mas outras infladas e lançadas pelas pessoas em nossa volta, e é preciso estar em alerta constante para defender as primeiras em relaçăo às últimas (BAUMAN, 2005, p. 18-19).
\end{abstract}

O autor ainda traz o termo chez soi (em casa) em oposiçăo à idéia do estar deslocado, e enfatiza que esse sentimento de estar em casa é muito frágil, apenas uma atitude 
desesperada, um sonho de pertencimento.

De volta à ficçăo, o ex-mágico pode ser entendido, entăo, como esse sujeito que nâo compreende a organizaçấo social na qual se vê inserido e que é obrigado a se tornar um refugiado de si mesmo. É o dono da taberna que o faz mágico, mas com a intençâo única de resolver um problema seu - a necessidade de atrair clientes. É também ele que, năo vendo mais lucro em manter o funcionário, o envia para o circo. Essas funçóes sâo atribuídas pelo outro e assumidas pelo protagonista, sem questionamentos. No entanto, ele nâo consegue compreender a sua funçâo social e isso está representado nas sequências narrativas em que ele nâo se envolve com o público.

A náo identidade resulta na nulidade do homem, condenando-o a uma existência sem razăo de ser, na qual, inicialmente, os truques mágicos o aprisionam e o afastam da convivência social; e, depois, ocupando um lugar social no qual ele nâo se realiza. Ao final, o ex-mágico amargura a existência dolorosa de năo encontrar espaço na sociedade, tampouco sobreviver fora dela.

Nós, leitores, percebemos esse sujeito sem uma consciência de si que o preparasse para as diferentes fases do enredo. Bauman (2005) atenta para o fato de que, na sociedade líquida, as identidades "flutuam no ar, algumas de nossa própria escolha, mas outras infladas e lançadas pelas pessoas em nossa volta" (p. 20) e devemos estar conscientes para defendermos as primeiras em vez das últimas. Quando năo há uma escolha consciente, essas identidades se alternam permanentemente e o resultado é a angústia. É o que vemos no presente conto, cujos traços do homem da sociedade líquido-moderna descrita por Zygmunt Bauman estâo presentes, antecipando elementos do que viria a ser o conto na modernidade líquida, tanto em sua estrutura quanto na temática.

Em nossa leitura, entendemos que uma forma encontrada por Rubiăo para representar a situaçăo política brasileira na época da Revoluçăo de 1930 foi a da escolha de palavras que fizessem referência a Portugal, que padecia com a evoluçăo do movimento salazarista. O restaurante em que o nosso protagonista surge é uma "taberna" e recebe o adjetivo "minhota"; do mesmo modo, o circo é o "Parque-Andaluz". Há, entâo, um deslocamento da ambientaçăo da narrativa para o país luso.

Nesse caso, as escolhas no campo textual teriam a funçâo de camuflar a história 2 - segundo a já mencionada teoria do conto moderno de Ricardo Piglia -, qual seja o regime político opressivo no Brasil do Estado Novo. Essa história submersa ainda é sinalizada em dois outros momentos, em que duas datas nos permitem a ligaçăo com o clima sócio-político brasileiro: "1930, ano amargo" (RUBIÂO, 1986, p. 56) e "1931 entrou triste" (Ibid., p. 57).

Uma das questôes debatidas por Zygmunt Bauman (2003) é a da falta de equilíbrio entre liberdade e segurança - um dilema que sempre acompanhará a humanidade -, pois, a partir do momento em que se faz a opçâo de viver em comunidade, se ganha proteçăo o que se perde em autonomia. Essas qualidades da vida em comunidade săo incompatíveis e igualmente desejadas:

A promoçăo da segurança sempre requer o sacrifício da liberdade, enquanto esta só pode ser ampliada à custa da segurança. Mas segurança sem liberdade equivale à escravidâo (...); e a liberdade sem segurança equivale a estar perdido e abandonado. Essa circunstância provoca nos filósofos uma dor de cabeça sem cura conhecida. Ela também torna a vida em comum um conflito sem fim, pois 
a segurança sacrificada em nome da liberdade tende a ser a segurança dos outros; e a liberdade sacrificada em nome da segurança tende a ser a liberdade dos outros (BAUMAN, 2003, p. 24).

A intensa agitaçăo política e cultural no Brasil quando se tem início a Era Vargas (1930-1945) é o reflexo do desequilíbrio da balança segurança/liberdade e é ilustrada, no conto muriliano, pela própria condiçăo da classe artística.

Em uma de suas tentativas de se livrar da condiçăo de mágico, o protagonista adquire uma arma; no entanto, ao atirar contra si "náo veio o disparo nem a morte: a mauser se transformara num lápis" (RUBIÂO, 1986 , p. 56). O lápis, outrora instrumento de criaçâo e liberdade, teria uma nova funçâo, qual seja a de vetar aquilo que năo fosse bom para a imagem do governo - o lápis se transformara no elemento cerceador da liberdade e garantidor da segurança do novo regime. Murilo Rubiăo claramente se serve das imagens contrastantes do lápis e da arma a fim de suscitar a discussâo do papel do escritor e da funçáo da literatura. O lápis - para o burocrata, instrumento de controle sobre o próximo -, nas máos do escritor é instrumento para denunciar os descaminhos sociais.

Em Portugal, Salazar havia criado o Secretariado da Propaganda Nacional, que cuidava da divulgaçăo do ideário de seu regime político. Nessa época, o "lápis azul" passou a representar o que havia sido aprovado por aquele órgáo fiscalizador, o que teve como consequência a padronizaçâo da cultura e das artes desse período.

Podemos ilustrar a balança liberdade versus segurança a partir da decisâo do protagonista de trocar a sua capacidade de fazer mágicas - náo aceitas pela sociedade - pela segurança do emprego na repartiçăo pública. Temos, assim, a liberdade propiciada pela livre expressáo artística sacrificada em prol da segurança e a consequente possibilidade de viver em comunidade. A falta de liberdade também pode significar uma perda de "direito à autoafirmaçấo e à identidade" (BAUMAN, 2003, p. 10), resultando na dificuldade de interaçâo, o que o torna um infeliz. A interaçâo, aqui, é entendida como possibilidade de o artista se expressar por meio de sua potencialidade criadora. No plano diegético, o ex-mágico náo consegue declarar o seu sentimento amoroso pela colega de repartiçấo, nem mesmo preservar o seu emprego (e o seu lugar) naquela sociedade controlada. É a burocracia a aniquiladora das capacidades criadoras - o mágico que tenta tirar do bolso algo que prove ao chefe que ele trabalhava ali há mais tempo -, impedindo o escritor de transformar a sua sociedade e se livrar daquele ambiente que o sufocava.

Antonio Candido (2006), a respeito do novo tratamento dado à forma nos textos literários produzidos em torno de 1940, comentou o efeito das mudanças instauradas pelos autores modernistas, que, atualizados quanto às novidades da arte de vanguarda europeia, "aprenderam a psicanálise e plasmaram um tipo ao mesmo tempo local e universal de expressáo" (p. 129). Por sua vez, Fábio Lucas, em $O$ caráter social da literatura brasileira (1976), ao examinar a situaçâo da ficçâo brasileira após a Segunda Guerra Mundial, abordou a questăo da valorizaçáo do conto como um efeito da crise do romance: 
[...] os ficcionistas preferem, modernamente, situaçôes dramáticas de curta duraçăo e psicológicas adaptadas às contingências do momento de intensidade emocional. Além do mais, aprimorou-se o gosto das soluçôes no plano verbal; a arte da ficçâo se tornou mais 'literária' (LUCAS, 1976, p. 122-3).

O crítico se referia ao movimento de renovaçăo na escrita literária brasileira, que năo se deu apenas quanto ao modo de pensar a sociedade, o indivíduo, a natureza ou as situaçóes cotidianas, mas, principalmente, por meio de uma nova forma de criar a realidade com a linguagem literária. A estética muriliana surgia, assim, ao mesmo tempo, como reflexo dessas influências e como um modo narrativo fundado no elemento insólito:

[...] Com segurança meticulosa e absoluta parcialidade pelo gênero (pois nada escreve fora dele), Murilo Rubiăo elaborou os seus contos absurdos num momento de predominância do realismo social, propondo um caminho que poucos identificaram e só mais tarde outros seguiram (LUCAS, 1976, p. 252).

No texto “A nova narrativa", publicado pela primeira vez em 1979, Antonio Candido referiu-se a Clarice Lispector, com Perto do coraçāo selvagem (1943), Guimaráes Rosa, com Sagarana (1946), e Murilo Rubiăo como "inovadores" e observou que, especialmente Rosa e Rubiăo, só anos mais tarde alcançaram visibilidade crítica.

A preocupaçăo de Murilo Rubiăo em ser aceito por público e crítica o colocava à mercê de uma força (incontrolável) que o levava ao reexame dos originais e, em seguida, à reescrita dos contos - o que, para ele, fazia parte do próprio processo de criaçăo do texto literário. Ao pensarmos na dedicaçâo do autor para com a construçâo de narrativas apuradas estilisticamente somos levados às "liçóes americanas" de Ítalo Calvino (1990) e suas ideias acerca dos valores com os quais a literatura (e quem produz literatura) deve se preocupar:

[...] no mais das vezes, minha intervençăo se traduziu por uma subtraçăo do peso; esforcei-me por retirar peso, ora às figuras humanas, ora aos corpos celestes, ora às cidades; esforcei-me, sobretudo, por retirar peso à estrutura narrativa e à linguagem (CALVINO, 1990, p. 15).

Calvino pensa na oposiçáo leveza-peso e termina por definir seu trabalho de criaçấo literária, o que nos leva ao trabalho de elaboraçáo da linguagem na escrita muriliana e, talvez mais ainda, ao fato de o autor repousar a sua ficçâo nos domínios do insólito.

O professor e pesquisador brasileiro Flávio García (2007), coordenando o Grupo de Pesquisa "Nós do Insólito" (UERJ), a fim de propor uma atualizaçăo do instrumental teórico que proporcionasse uma melhor e mais adequada análise interpretativa de narrativas do insólito estudadas pelo seu Grupo, sugeriu uma nova terminologia representativa da contemporaneidade: o "insólito banalizado". Segundo o autor, nessa categoria operacional, os eventos insólitos:

Acabam aceitos sem a possibilidade de serem impedidos de acontecer ou explicados quanto à sua razăo ou natureza, săo, entấo, banalizados como algo possível de acontecer na experiência cotidiana, bem próximo do absurdo sem, contudo, configurarem uma denúncia que busque a transformaçăo, mas como uma constataçăo desesperadora da realidade vivenciável ou vivenciada (GARCÍA, 2007, p.14). 
Em outra publicaçăo, no entanto, García (2010) observou que a terminologia é de caráter experimental e, portanto, carece de maiores estudos de análise que comprovem a sua manifestaçăo em uma gama maior de produçôes literárias de autores diversos (p. 41).

Em nosso entendimento, pensando na definiçăo de "banal" como aquilo que é corriqueiro, existe mesmo a banalizaçăo do insólito no conto "O ex-mágico da Taberna Minhota", uma vez que os eventos insólitos nâo ocasionais pretendem a uma vulgarizaçăo dos acontecimentos que fogem às regras tidas como normais, a fim de causar ao leitor nâo um estranhamento, e sim a sua identificaçâo com a angústia do narrador-protagonista.

Ao revermos o nossos estudos sobre a modernidade líquida e os efeitos da fluidez identitária, assim como descritos por Zygmunt Bauman, podemos afirmar que a narrativa que tem na banalizaçăo do evento insólito o seu traço distintivo corresponde a uma das formas literárias representativas dessa sociedade líquido-moderna.

\section{CONSIDERAÇÕES FINAIS}

"Inclina, Senhor, o teu ouvido, e ouve-me; porque eu sou desvalido e pobre" a epígrafe de "O ex-mágico da Taberna Minhota" é bíblica, um excerto do Salmo 86, Oraçấo de Davi. A respeito deste salmo, a Bíblia Sagrada traz a seguinte nota: "Oraçăo de súplica individual em tempo de perigo e perseguiçâo. O salmo é composto de duas séries de súplicas, com motivos para Deus atuar em seu favor" (BÍBLIA SAGRADA). É também em tom de súplica que o narrador-protagonista, no último parágrafo, deseja:

[...] arrancar do corpo lenços vermelhos, azuis, brancos, verdes. Encher a noite com fogos de artifício. Erguer o rosto para o céu e deixar que pelos meus lábios saísse o arco-íris. Um arco-íris que cobrisse a terra de um extremo a outro. E os aplausos dos homens de cabelos brancos, das meigas criancinhas (RUBIÂO, 1986, p. 57).

Em tempo, relembramos um dos títulos (provisórios) do livro de estreia de Murilo Rubiăo (O ex-mágico, 1947), "O dono do arco-íris", e pensamos na simbologia do arco-íris, segundo Chevalier \& Gheerbrant (2006), "a ponte de que se servem deuses e heróis, entre o Outro-mundo e o nosso" (p.77). É possível, entâo, relacionar este elemento, que também aparece no último parágrafo do conto analisado, com a figura do mágico - que poderia "criar todo um mundo mágico" (RUBIÂO, 1986, p. 57) - e do escritor, que utiliza o lápis e as palavras, criando jogos de imagem textuais para imprimir sua crítica social.

A literatura como forma de resistir à opressăo social e política. A arte como um modo de salvar o homem moderno de suas angústias existenciais, permitindo-lhe um 'desacelerar' - essencial à tomada de consciência de si no mundo em transformaçấo. É, entăo, a literatura a possibilidade de o "sujeito fragmentado" se recompor. Talvez seja o mágico das palavras, um desfragmentador, o que implicaria em dizer que Murilo Rubiăo se colocou na contramăo da sociedade líquida ao assumir-se como um homem solitário, que conseguia enxergar o absurdo cotidiano, sofrer com isso, e, ao mesmo tempo, optar por um modo narrativo que, apesar de fruto da dissoluçăo, anseia por uma reestruturaçăo. 
Murilo Rubiăo se inscreve na historiografia literária brasileira nâo apenas como o precursor do fantástico, mas como um escritor muito sensível, dotado de inteligência poética e de um estilo peculiar, que soube traduzir as angústias de uma época em nossa sociedade que só se consolidariam nas produçóes literárias nacionais alguns anos depois.

\section{REFERÊNCIAS}

BAUMAN, Z. Modernidade líquida. Trad. Plinio Dentzien. Rio de Janeiro: Jorge Zahar, 2001.

. Comunidade: a busca por segurança no mundo atual. Trad. Plinio Dentzien. Rio de Janeiro: Jorge Zahar, 2003.

Identidade. Trad. Carlos Alberto Medeiros. Rio de Janeiro: Jorge Zahar, 2005.

. Vida líquida. Trad. Carlos Alberto Medeiros. Rio de Janeiro: Jorge Zahar, 2007.

. Diálogos com Zygmunt Bauman: entrevista. [25 de julho de 2011] Londres: Produçâo CPFL Cultura e Seminário Fronteiras do Pensamento, 2011. Entrevista concedida ao Núcleo de Pesquisa em Estudos Culturais Npec. Disponível em: <http://www.cpflcultura. com.br/2011/08/16/dialogos-com-zygmunt-bauman/>. Acesso em 02/02/2018.

BESSIĖRE, I. O relato fantástico: forma mista do caso e da adivinha. Trad. Biagio D'Angelo e Maria Rosa Duarte de Oliveira. FronteiraZ, Săo Paulo, n. 09, dez. 2012.p. 305-319. Disponível em: < https://revistas.pucsp.br/index.php/fronteiraz/article/ view/12991/9481 >. Acesso em 28/03/2018.

BÍBLIASAGRADA. Salmo 86: oraçâo de Davi. Trad. Luís Stadelmann. 52. ed. Rio de Janeiro: Vozes, 2012, p. 737.

CANDIDO, A. Literatura e cultura: de 1900 a 1945. In: . Literatura e sociedade. 9. ed. Rio de Janeiro: Ouro sobre Azul, 2006.

A nova narrativa. In: A educaçâo pela noite. 6. ed. Rio de Janeiro: Ouro sobre Azul, 2011, p. 241-260.

CALVINO, I. Seis propostas para o novo milênio: liçōes americanas. Trad. Ivo Barroso. Sāo Paulo: Companhia das Letras, 1990.

CHEVALIER, J.; GHEERBRANT, A. Dicionário de símbolos. 20. ed. Trad. Vera da Costa e Silva. Rio de Janeiro: José Olympio, 2006, p. 77-79.

FURTADO, F. Fantástico: modo. E-Dicionário de Termos Literários. Coord. Carlos Ceia. 2009. Disponível em: 〈http://edtl.fcsh.unl.pt/encyclopedia/fantastico-modo/〉. Acesso em 28/04/2018.

GAMA-KHALIL, Marisa Martins. A literatura fantástica: gênero ou modo. Terra 
Roxa e outras terras: Revista de Estudos Literários. Londrina, vol. 26, dez./2013. p. 18-31. Disponível em: 〈http://www.uel.br/pos/letras/terraroxa〉. Acesso em $15 / 03 / 2018$.

GARCÍA, F. O insólito na narrativa ficcional: a questăo e os conceitos na teoria dos gêneros literários. In:__. (Org.) A banalizaçâo do insólito: questōes de gênero literário - mecanismos de construçăo narrativa. Rio de Janeiro: Dialogarts, 2007. Disponível em: <http:// www.dialogarts.uerj.br/admin/arquivos_tfc_literatura/livro_insolito.pdf〉. Acesso em 13/03/2018.

. O insólito na narrativa de Mário de Carvalho: uma questăo de gênero literário. Revista Augustus. Rio de Janeiro, ano 15, n. 30, ago./2010.p.34-41. Disponível em: <http:// apl.unisuam.edu.br/augustus/images/edicao30/pdf/rev_aug_30_art03.pdf〉. Acesso em 28/03/2018.

- Fantástico: a manifestação do insólito ficcional entre modo discursivo e gênero literário - literaturas comparadas de língua portuguesa em diálogo com as tradiçóes teórica, crítica e ficcional. Anais. XII Congresso Internacional da ABRALIC, Curitiba/ PR, 18-22 jul. 2011. Disponível em: < http://www.abralic.org.br/eventos/cong2011/ AnaisOnline/resumos/TC0010-1.pdf>. Acesso em 07/03/2018.

LOVECRAFT, H. P. O horror sobrenatural em literatura. Trad. Celso M. Paciornik. Sáo Paulo: Iluminuras, 2007.

LUCAS, F. O caráter social da literatura brasileira. 2. ed. Sāo Paulo: Quíron, 1976.

LUKÁCS. G. A teoria do romance. Trad., posfácio e notas José Marcos Mariani de Macedo. Sāo Paulo: Duas Cidades/Ed34, 2000.

PALLARES-BURKE, M. L. G. Entrevista com Zigmunt Bauman. Tempo social. São Paulo: EdUSP, vol. 16, n. 1, 2004, p. 301-325. Disponível em: <http://www.scielo.br/ pdf/ts/v16n1/v16n1a15.pdf>. Acesso em 13/03/2018.

PIGLIA, R. Formas breves. Trad. José Marcos Mariani de Macedo. Sâo Paulo: Companhia das Letras, 2004.

PRADA OROPEZA, R. El discurso fantástico contemporâneo: ténsion semântica y efecto estético. Revista Semiosis. Tercera época, vol. 2, n. 3, p. 54-76, 2006.

RUBIĀO, M. O pirotécnico Zacarias. Sáo Paulo: Ática, 1986.

- Murilo Rubiâo: obra completa. Ediçâo do Centenerário. Textos críticos: Jorge Schwartz e Carlos de Brito e Mello. São Paulo: Companhia das Letras, 2016.

SARTRE, J. P. O existencialismo é um humanismo. Trad. Rita Correia Guedes. 3. ed. Săo Paulo: Nova Cultural, 1987.

SCHWARTZ. J. Murilo Rubiāo: a poética do uroboro. Sāo Paulo: Ática, 1981. 
TODOROV, T. Introduçâo à literatura fantástica. Trad. Maria Clara Correa Castello. Sáo Paulo: Perspectiva, 2007.

WERNECK, H. A aventura solitária de um grande artista. 1988. In: RUBIẢO, M. O pirotécnico Zacarias e outros contos. Sáo Paulo: Companhia das Letras, 2006.

Submetido em 24 de março de 2018

Aceito em 16 de julho de 2018 